\title{
Effect of Carbon Stabilizing Elements on WC Cemented Carbides with Chromium Steel Binder
}

\author{
Marek TARRASTE ${ }^{1}$ *, Jakob KÜBARSEPP ${ }^{1}$, Kristjan JUHANI ${ }^{1}$, Arvo MERE ${ }^{2}$, \\ Mart VILJUS ${ }^{1}$
}

${ }^{1}$ Department of Mechanical and Industrial Engineering, Tallinn University of Technology, Ehitajate tee 5, 19086 Tallinn,
Estonia
${ }^{2}$ Department of Materials and Environmental Technology, Tallinn University of Technology, Ehitajate tee 5, 19086 Tallinn,
Estonia

crossref http://dx.doi.org/10.5755/j01.ms.25.2.19619

Received 07 December 2017; accepted 25 April 2018

\begin{abstract}
High price, limited availability and toxicity of cobalt motivates researchers and material engineers to find alternative binder systems for WC cemented carbides. Iron and iron alloys are promising candidates for complete cobalt substitution. Ferritic steels alloyed with chromium can offer an inexpensive binder system to acquire cemented carbides with enhanced oxidation and corrosion resistance. Since $\mathrm{Fe}$ and $\mathrm{Cr}$ are carbide formers, production of $\mathrm{WC}-\mathrm{FeCr}$ cemented carbides with a desirable two-phase structure can be problematic. Niobium and titanium are strong carbide formers and well-known alloying elements in steels used to stabilize carbon, preventing formation of unwanted chromium carbide phases. In our work, WC-FeCr was alloyed with elemental $\mathrm{Nb}$ and Ti. The phase composition, structure morphology and mechanical properties of prepared cemented carbides were characterized and discussed. As a result, additions of carbon stabilizing elements enabled us to improve structural homogeneity and wear resistance of WC cemented carbides with ferritic a steel binder.
\end{abstract}

Keywords: cemented carbides, alternative binder, erosion resistance, microstructure evolution.

\section{INTRODUCTION}

The necessity to reduce or even avoid toxic elements such as cobalt and nickel in engineering materials is intensified by various regulations $[1,2]$. However, these elements are preferred as binder in tungsten cemented carbides. WC-Co system show exceptional mechanical and tribological performance and WC-Ni offers enhanced oxidation/corrosion resistance. Iron as a potential binder metal was excluded in the early 1930s due to its inferior mechanical properties, but in the recent decades, studies have increasingly focused on Fe-binder. Several complications with $\mathrm{Fe}$ as a base binder metal have been resolved by addressing the crucial effect of carbon balance [3] and the usage of calculated phase diagrams [4]. With binder systems such as FeNi, FeCoNi, FeNiCr, FeMn, etc., researchers have achieved positive and often superior results, even surpassing those of WC-Co [5-7].

$\mathrm{Co}$ and $\mathrm{Ni}$ free WC cemented carbides with the $\mathrm{FeCr}-$ based binder have received limited attention. Hinners et al. prepared hardfacing where $\mathrm{WC}$ and $\mathrm{M}_{\mathrm{x}} \mathrm{C}_{\mathrm{y}}$ particles were embedded in $\mathrm{Fe}(\mathrm{Cr})$ matrix [8]. Sakaguchi et al. and Kambakas et al. focus on the high chromium grey cast irons with WC reinforcement $[9,10]$. Our studies of the $\mathrm{FeCr}$ binder system have shown that it is challenging to achieve a uniform structure without using very fast consolidation processes (e.g. SPS) [11, 12], due to carbon activity, Fe and Cr mixed metal carbides form (Fig. 1). Kambakas et al. have shown how active the cast iron and WC system is in terms of phase formations. According to their study, during casting, various $\mathrm{M}_{\mathrm{x}} \mathrm{C}_{\mathrm{y}}$ primary and eutectic carbides were formed. $\mathrm{M}_{\mathrm{x}} \mathrm{C}_{\mathrm{y}}$ carbides can have a detrimental effect on the properties of bulk WC cemented carbides.

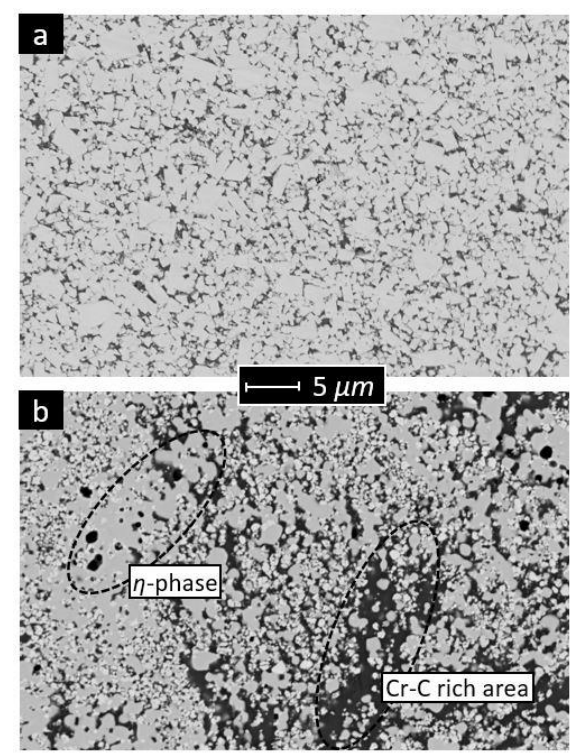

Fig. 1. WC-Co microstructure: a-exhibits favourable uniform two phase structure with WC grains in Co matrix. In the WC-FeCr microstructure; $\mathrm{b}$ - presence of secondary metal carbides yields heterogeneous microstructure

\footnotetext{
${ }^{*}$ Corresponding author. Tel.: +372-6203357.

E-mail address: marek.tarraste@gmail.com (M. Tarraste)
} 
The most prevalent method to retard the formation of $\mathrm{Fe}$ - and Cr-based metal carbides in steels is the addition of strong monocarbide forming elements [13].

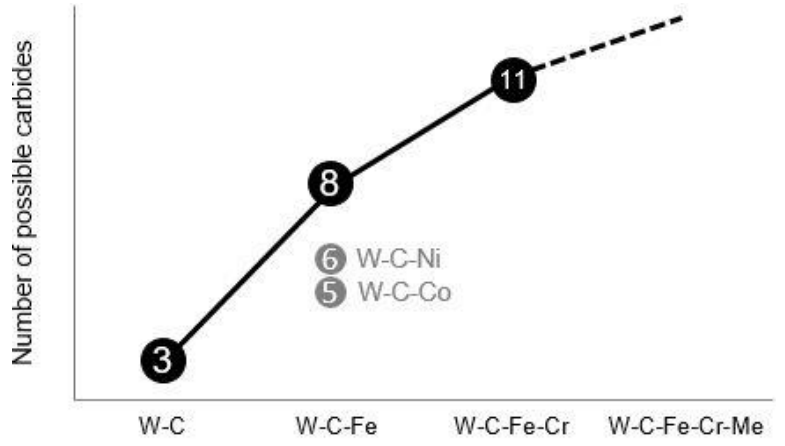

Fig. 2. Number of possible carbides in WC hardmetal systems according to $[14,15]$

However, due to the carbon active nature of $\mathrm{Fe}$ and $\mathrm{Cr}$ the number of possible carbide phases in $\mathrm{WC}-\mathrm{Fe}(\mathrm{Cr})$ cemented carbides is already greater than in conventional WC-Co/Ni systems (Fig. 2). The addition of active carbide formers to the W-C-Fe-Cr system could complicate the final phase composition even further.

Our aim of this research is to study the effect of carbideforming elements $\mathrm{Ti}$ and $\mathrm{Nb}$ on the microstructure and properties of $\mathrm{WC}-\mathrm{FeCr}$ cemented carbides.

\section{EXPERIMENTAL}

Cemented carbide powder mixtures with a ferritic chromium steel AISI430L ( $\left.\mathrm{Fe}_{81.8}-\mathrm{Cr}_{16.8}-\mathrm{Mn}_{0.7}-\mathrm{Si}_{0.7}\right)$ binder and $\mathrm{Ti} / \mathrm{Nb}$ additions were prepared by the conventional milling technique: $\mathrm{WC}$, steel, $\mathrm{Ti} / \mathrm{Nb}$ and graphite powders were milled in a ball mill with hardmetal lining and balls for $144 \mathrm{~h}$ with the ball-to-powder weight ratio of 10:1. Isopropyl alcohol was used as a milling liquid. Chemical composition of prepared mixtures and reference materials are presented in Table 1. Graphite powder as an extra carbon source was included to minimize decomposition of the WC phase due to the formation additional $\mathrm{M}_{\mathrm{x}} \mathrm{C}_{\mathrm{y}}$ phases, especially after liquid phase sintering. As compared with traditional WC-Co cemented carbides, experimental WCSTi and WCS-Nb as well as WCS mixtures were prepared with drastically increased metal fraction to guarantee the presence of metal matrix after the formation of various additional carbide phases.

Milled powders mixed with $3 \mathrm{wt} . \%$ paraffin were dried at $50{ }^{\circ} \mathrm{C}$ and compacted into green bodies with $95 \mathrm{MPa}$ of uniaxial pressure. Conventional liquid phase sintering in vacuum $(0.1 \ldots 0.5$ mbar $)$ was carried out in a sinter-HIP furnace FPW 300/400 from FCT Systeme GmbH. Pressed samples were placed on zirconia support in graphite crucibles. Heating rate was $10^{\circ} \mathrm{C} / \mathrm{min}$ and $30 \mathrm{~min}$ dwell at the end temperature, followed by natural cooling with the furnace. WCS-(Ti/Nb) materials were sintered at $1300{ }^{\circ} \mathrm{C}$ while WC-Co reference materials were sintered at $1400-1450{ }^{\circ} \mathrm{C}$. Respective sintering temperatures yielded specimens with near full density and minimal porosity $(<0.2 \%)$. Zeiss EVO MA15 scanning electron microscope (SEM) equipped with an Oxford Instruments INCA Energy EDS system was used for microstructure observation and assessment of elemental distribution. X-ray diffraction (XRD) measurements of the samples were performed on a Rigaku Ultima IV diffractometer with monochromatic $\mathrm{Cu}$ $\mathrm{K} \alpha$ radiation $(\lambda=1.5406 \AA)$ at $40 \mathrm{kV}$ and $40 \mathrm{~mA}$ using the silicon strip detector D/teX Ultra. All samples were studied in the $2 \theta$ range of $28-55 \mathrm{deg}$ with the scan step of $0.02 \mathrm{deg}$. Vickers hardness was measured with Indetec 5030. The indentation fracture toughness $\left(K_{\mathrm{IC}}\right)$ was determined by measuring the crack length from the tip of the indentation made by Vickers indentation (Palmqvist method) and calculated by the following equation [16]:

$K_{I C}=0.15 \sqrt{\frac{H V 30}{\sum l}}$,

where $\sum l$ is the sum of the crack length of the crack tip from the hardness indent in $\mathrm{mm}$. The erosion wear of prepared cemented carbides in room and in elevated temperatures was measured with the help of the four channel centrifugal high temperature erosion wear tester described in [17]. Silica particles with a mean size $0.3 \mathrm{~mm}$ were chosen as erodent. Particles with the velocity of $80 \mathrm{~m} / \mathrm{s}$ hit specimens at the angle of $30^{\circ}$. During all tests the atmosphere was air to simulate erosion-oxidation conditions.

\section{RESULTS AND DISCUSSION}

\subsection{Microstructure and phase composition}

Backscatter SEM images of WCS-(Ti/Nb) cemented carbides with respective $\mathrm{Cr}$ mappings are presented in Fig. 3. Small magnification renders a good overview of phase distribution and with the corresponding $\mathrm{Cr}$ elemental signal, it is evident that addition of $\mathrm{Ti}$ and $\mathrm{Nb}$ promotes the development of more a homogeneous structure. Large elongated Cr-rich binder pools, often over several hundred micrometre long, are not present in materials WCS-(Ti/Nb). The $\eta$-phase, almost not present in WCS, is formed in materials alloyed with $\mathrm{Ti}$ and $\mathrm{Nb}$ (Fig. 4 and Fig. 5).

Table 1. Composition of prepared powder mixtures and mechanical properties of respective sintered cemented carbides

\begin{tabular}{|c|c|c|c|c|c|c|c|c|c|c|c|}
\hline \multirow{2}{*}{$\begin{array}{c}\text { Material } \\
\text { designation }\end{array}$} & \multicolumn{9}{|c|}{ Composition, wt.\% } & \multirow{2}{*}{$\begin{array}{c}\text { Hardness, HV30 } \\
\mathrm{kgf} / \mathrm{mm}^{2}\end{array}$} & \multirow{2}{*}{$\begin{array}{c}\text { Indentation fracture } \\
\text { toughness } \\
\mathrm{MPa}^{*} \mathrm{~m}^{1 / 2}\end{array}$} \\
\hline & WC & $\mathrm{Co}$ & $\mathrm{Fe}$ & $\mathrm{Cr}$ & $\mathrm{Mn}$ & $\mathrm{Si}$ & $\mathrm{C}$ & $\mathrm{Ti}$ & $\mathrm{Nb}$ & & \\
\hline WCS-Ti & 69 & - & 20.2 & 4.1 & 0.2 & 0.2 & 1.5 & 4.9 & - & $1237 \pm 13$ & $8.7 \pm 0.1$ \\
\hline WCS-Nb & 69 & - & 20.2 & 4.1 & 0.2 & 0.2 & 1.5 & - & 4.9 & $1340 \pm 28$ & $8.5 \pm 0.2$ \\
\hline WCS & 69 & - & 24.2 & 5.0 & 0.2 & 0.2 & 1.5 & - & - & $1204 \pm 49$ & $\mathrm{n} / \mathrm{a}^{*}$ \\
\hline WC-11Co & 89.0 & 11.0 & - & - & - & - & - & - & - & $1489 \pm 24$ & $13.8 \pm 0.3$ \\
\hline WC-15Co & 85.0 & 15.0 & - & - & - & - & - & - & - & $1274 \pm 16$ & $17.5 \pm 1.1$ \\
\hline
\end{tabular}



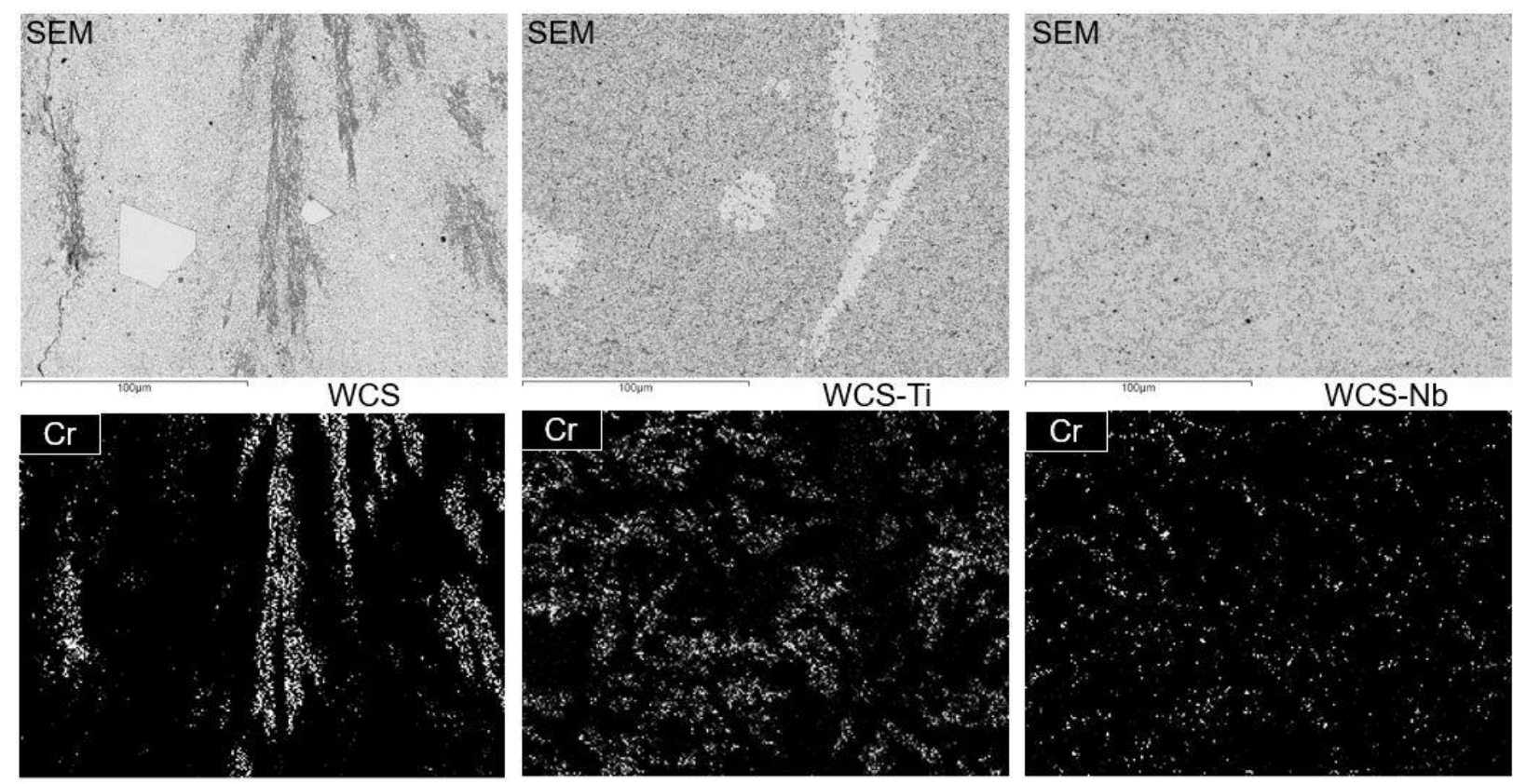

Fig. 3. BS-SEM images and elemental maps of Cr: WCS (left), WCS-Ti (middle) and WCS-Nb (right). Areas with increased Cr concentration are marked as white on elemental maps
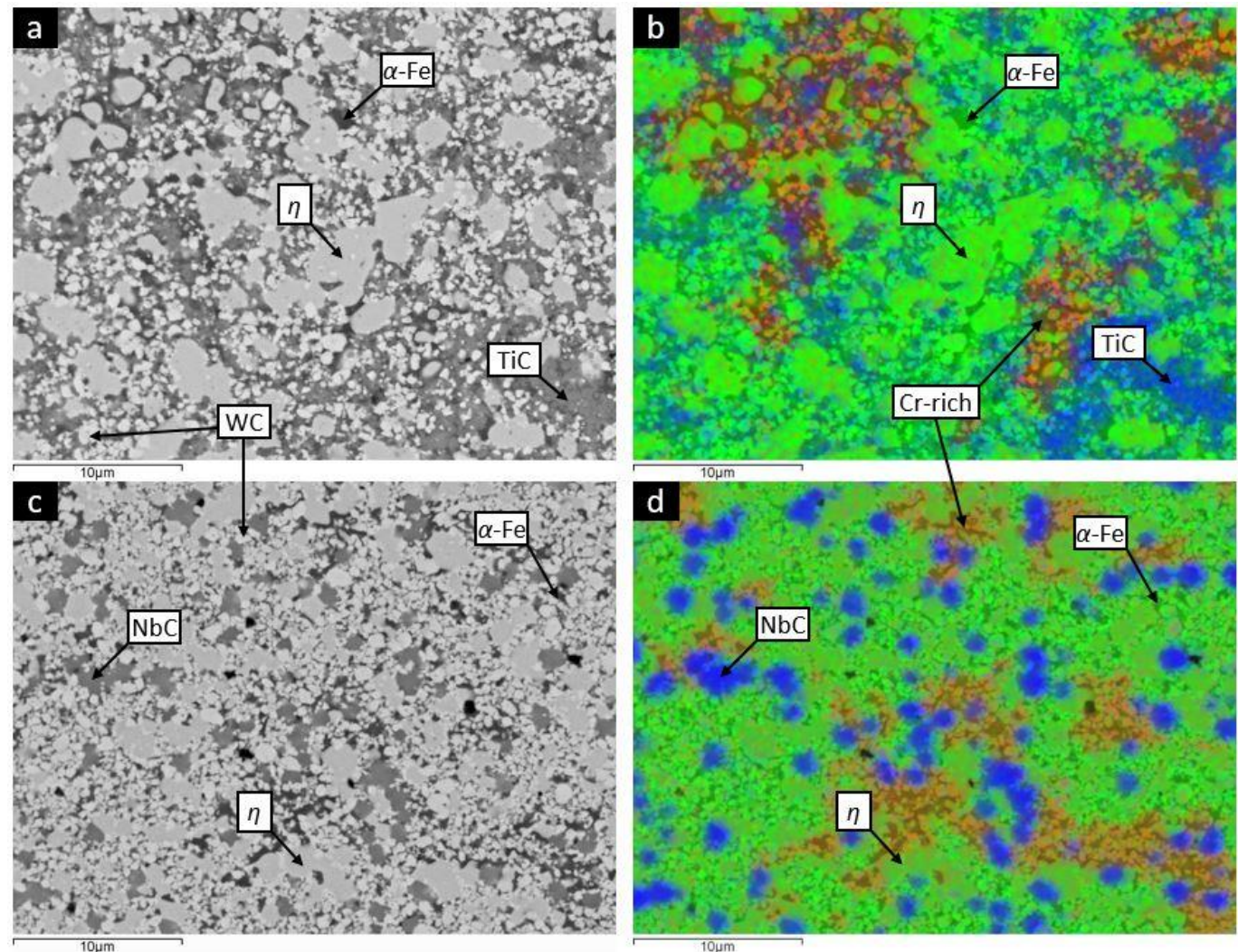

Fig. 4. BS-SEM images coupled with EDS mappings of WCS-Ti $(a, b)$ and $\mathrm{WCS}-\mathrm{Nb}(\mathrm{c}, \mathrm{d})(\mathrm{green}=\mathrm{Fe}, \mathrm{red}=\mathrm{Cr}, \mathrm{blue}=\mathrm{Ti} / \mathrm{Nb})$

With the help of the EDS and XRD analysis, it was determined to be the type of $(\mathrm{Fe}, \mathrm{W}, \mathrm{Cr})_{6} \mathrm{C}$ with the $\mathrm{Fe}: \mathrm{W}: \mathrm{Cr}$ ratio close to $5: 5: 1$. The shape of that phase depends on the material. Only in the microstructure of WCS-Nb $\eta$-phase appears as uniformly distributed $1-3 \mu \mathrm{m}$ sized grains (Fig. 3 and Fig. 4 c). BS-SEM microstructure images and respective EDS elemental mappings of experimental cemented carbides (Fig. 4) with higher magnification demonstrate three distinguishable areas with different elemental composition: three carbide phases (WC, $\eta$-phase, $\mathrm{TiC}$ or $\mathrm{NbC}$ ) and two metal rich phases. Due to the relatively large interaction volume of EDS analysis method $(\geq 1 \mu \mathrm{m} \emptyset)$ coupled with submicron structure of experimental materials, we were unable to employ EDS spot analysis to acquire precise quantitative elemental data of other phases besides $\eta$-phase. TiC and $\mathrm{NbC}$ are both cubic carbides and other refractory metals (W, V, Mo, Cr) are soluble in them. In the current work with EDS, a dissolution 
of $16 . .20 \mathrm{wt} . \%$ of $\mathrm{W}$ in $\mathrm{Ti}$ and $\mathrm{Nb}$ carbides was approximated.

According to the XRD results Fe-rich phase is ferrite, $\alpha$-Fe with the bcc crystal structure. The presence of $\alpha$-Fe instead of fcc structured $\gamma$-Fe is in good accordance with literature [18]. $\mathrm{Cr}$ is soluble in $\alpha$-Fe, thus forming $\mathrm{Fe}-\mathrm{Cr}$ solid solution. However, in the materials, $\mathrm{Cr}$ content in solid solution was not over $5 \mathrm{wt}$ \% and even taking account high uncertainty of EDS, it is still considerably lower than the in starting material (16.8 wt.\% in AISI430L steel), thus confirming the formation of $\mathrm{Cr}$-carbides. In the $\mathrm{Fe}-\mathrm{Cr}-\mathrm{C}$ system during cooling from liquid phase, eutectic transformation follow $\mathrm{L} \rightarrow \mathrm{fcc}+\mathrm{M}_{7} \mathrm{C}_{3}$ and later fcc starts decomposing into bcc and $\mathrm{M}_{23} \mathrm{C}_{6}$ [19]. Thus, a Cr-rich phase in the WCS material consists mainly of $\mathrm{Cr}$ carbides with their shape similar to the $(\mathrm{Cr}, \mathrm{M})_{\mathrm{x}} \mathrm{C}_{\mathrm{y}}$ carbides reported by Kambakas [10]. In the WCS-Ti/Nb materials, the formation of large elongated $\mathrm{Cr}$-rich areas is retarded, which indicates that upon solidification eutectic-like mixture of $\mathrm{M}_{\mathrm{x}} \mathrm{C}_{\mathrm{y}}$ and $\alpha$ Fe based solid solution is formed. This confirms that the addition of $\mathrm{Ti}$ and $\mathrm{Nb}$ had a desired effect on the microstructure, i.e., $\mathrm{TiC}$ and $\mathrm{NbC}$ as more stable carbides form preferably and thereby the fraction of Cr-based carbides is reduced. Traces of $\gamma$-Fe were also detected in the WCS-Ti material. This residual fcc phase indicates that decomposition of fcc was not finished during the cooling cycle and metallic phase could be in a metastable condition.

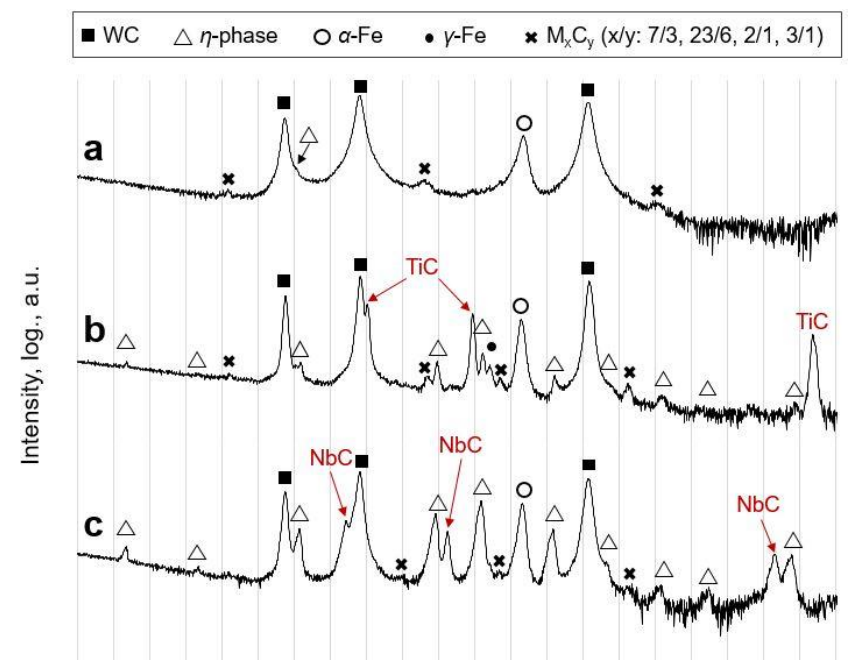

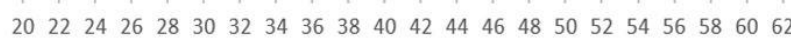
$2 \theta, \operatorname{deg}$

Fig. 5. XRD results of materials: a-WCS; b-WCS-Ti; $\mathrm{c}-\mathrm{WCS}-\mathrm{Nb}$

\subsection{Mechanical properties and wear performance}

Mechanical properties presented in Table 1 reveal that while hardness of WCS-(Ti/Nb) cemented carbides is comparable with that of $\mathrm{WC}-15 \mathrm{Co}$, the indentation fracture toughness is considerably lower even, when compared with that of WC-11Co. Achieving good toughness values with the Fe-based binder is complicated even with relatively straightforward WC-Fe system because of the stability of the $\mathrm{M}_{6} \mathrm{C}$ phase [20]. With the materials discussed in our work, it is especially difficult because of the high total fraction of carbides and the low fraction of completely carbide free binder phase. However, an improvement was achieved with the addition of $\mathrm{Ti}$ and $\mathrm{Nb}$ since their absence results in a microstructure too disturbed by $\mathrm{Cr}$-rich areas to enable the measurement of fracture toughness with indentation (Palmqvist method).

Erosion wear tests at room and elevated temperatures were carried out to investigate the performance of cemented carbides with the $\mathrm{FeCr}$ based binder system in erosionoxidation environment and compare them with regular WCCo grades (Fig. 6). At room temperature, WC-11Co and WC-15Co exhibit superior wear resistance; however, their performance begins to deteriorate when the temperature is increased. The advantage of the materials with a steel binder and with and without additional carbide forming elements can be explained with a lower fraction of WC and higher fraction of more oxidation resistant $\mathrm{Ti}$-, $\mathrm{Nb}$ - and $\mathrm{Cr}$-carbides [21]. The WCS-Ti material with $\mathrm{TiC}$ in the microstructure showed particularly good wear resistance at higher temperatures.

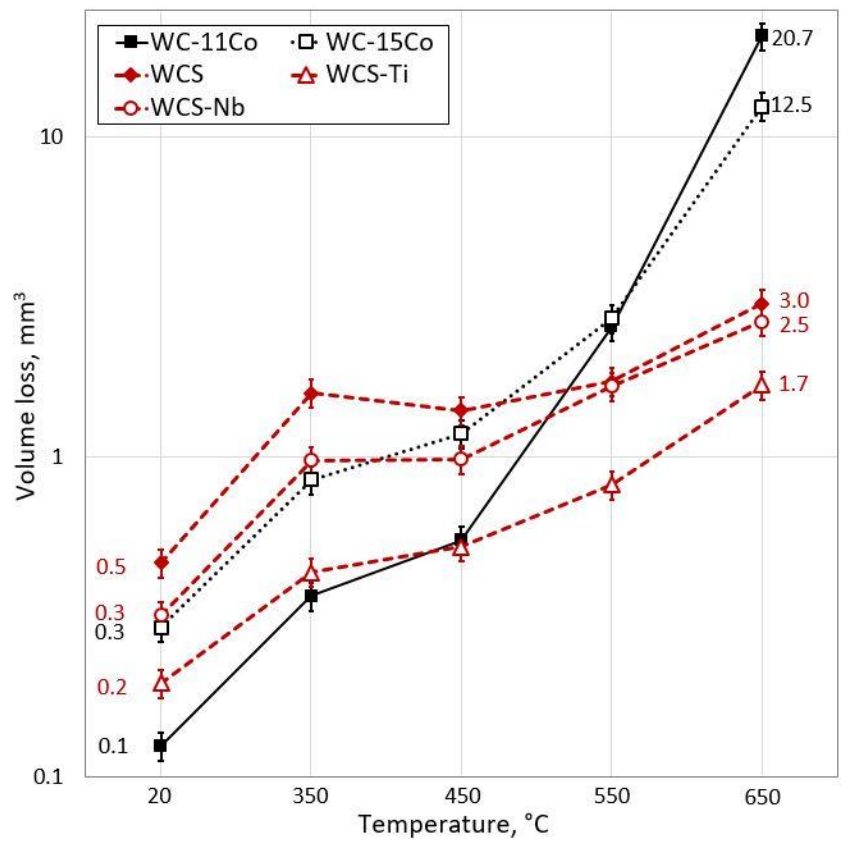

Fig. 6. Erosion wear at room and elevated temperatures of cemented carbides with $\mathrm{FeCr}$ and $\mathrm{Co}$ binder

\section{CONCLUSIONS}

WC-based cemented carbides with a ferritic chromium steel binder alloyed with carbon active elements $\mathrm{Ti}$ and $\mathrm{Nb}$ were prepared. The following conclusions can be drawn:

1. The addition of active monocarbide formers promotes the formation of a more homogeneous microstructure. The formation of Cr-carbide rich areas that disturb the microstructure is retarded.

2. Phase composition of experimental materials is relatively complex - besides $\mathrm{W}$ and $\mathrm{Ti}$ or $\mathrm{Nb}$ monocarbides the structure consists of $\mathrm{M}_{6} \mathrm{C}$ type $\eta$ phase and different $\mathrm{M}_{\mathrm{x}} \mathrm{C}_{\mathrm{y}}$ metal carbides.

3. Materials with $\mathrm{FeCr}$ binder show improved erosive wear resistance at elevated temperatures when compared with conventional WC-Co cemented carbides.

4. Fracture toughness of materials with a $\mathrm{FeCr}$ binder system suffers due to the carbide rich microstructure. 


\section{Acknowledgments}

This work was supported by institutional research fundings IUT (19-29) and IUT (19-4) of the Estonian Ministry of Education and Research and by the European Regional Development Fund project TK141 “Advanced materials and high-technology devices for energy recuperation systems".

\section{REFERENCES}

1. "REACH-Chemicals-Environment-European Commission." http://ec.europa.eu/environment/chemicals/reach/reach_en.ht m. [30.5.2017].

2. "National Toxicology Program." https://ntp.niehs.nih.gov/. [30.5.2017].

3. Agte, C. Die Neue Hochleistungshartsmetallsorte S6HL. Neue Hütte 1, 1956: p. 333.

4. Gustafson, P. A Thermodynamic Evaluation of the C-Cr-FeW System Metallurgical Transactions A 19 1988: pp. 2547-2554. https://doi.org/10.1007/BF02645482

5. Fernandes, C.M., $\quad$ Vilhena, L.M., $\quad$ Pinho, C.M.S., Oliveira, F.J., Soares, E., Sacramento, J., Senos, A.M.R. Mechanical Characterization of WC-10 wt\% AISI 304 Cemented Carbides Materials Science and Engineering A 618 2014: pp. 629-636. https://doi.org/10.1016/j.msea.2014.09.064

6. Prakash, L., Holleck, H., Thümler, F., Walter, P. The Influence of the Binder Composition on the Properties of WC$\mathrm{Fe} / \mathrm{Co} / \mathrm{Ni}$ Cemented Carbides Modern Developments in Powder Metallurgy 14 1981: pp. 255-268.

7. Hanyaloglu, C., Aksakal, B., Bolton, J.D. Production and Indentation Analysis of $\mathrm{WC} / \mathrm{Fe}-\mathrm{Mn}$ as an Alternative to Cobalt-bonded Hardmetals Materials Characterization 47 (3-4) 2001: pp. 315-322. https://doi.org/10.1016/S1044-5803(02)00181-X

8. Hinners, H., Konyashin, I., Ries, B., Petrzhik, M., Levashov, E.A., $\quad$ Park, D., $\quad$ Weirich, T., Mayer, J., Mazilkin, A.A. Novel Hardmetals with Nano-grain Reinforced Binder for Hard-facings International Journal of Refractory Metals and Hard Materials 67 2017: pp. $98-104$. https://doi.org/10.1016/j.ijrmhm.2017.05.011

9. Sakaguchi, S., Imasato, S., Ito, H., Nakamura, R. Some Properties of Sintered WC-(Fe-Cr-C) Alloys Journal of the Japan Society of Powder and Powder Metallurgy 36 (8) 1989: pp. $908-912$. https://doi.org/10.2497/jjspm.36.908

10. Kambakas, K., Tsakiropoulos, P. Solidification of High-Cr White Cast Iron-WC Particle Reinforced Composites
Materials Science and Engineering A 413-414 2005: pp. $538-544$.

https://doi.org/10.1016/j.msea.2005.08.215

11. Tarraste, M., Juhani, K., Kübarsepp, J., Pirso, J., Mikli, V. The Effect of $\mathrm{Cr}$ and $\mathrm{C}$ on the Characteristics of WC-FeCr Hardmetals Proceedings of Euro PM2015 2015.

12. Tarraste, M., Kübarsepp, J., Juhani, K., Suurkivi, T., Pirso, J. Spark Plasma Sintering of WC Hardmetals with Febased Binder Proceedings of World PM2016 2016.

13. Lo, K.H., Shek, C.H., Lai, J.K.L. Recent Developments in Stainless Steels Materials Science and Engineering: $R$ : Reports 65 (4) 2009: pp. 39-104. https://doi.org/10.1016/j.mser.2009.03.001

14. Fernandes, C.M., Senos, A.M.R. Cemented Carbide Phase Diagrams: A Review International Journal of Refractory Metals and Hard Materials 29 (4) 2011: pp. 405-418. https://doi.org/10.1016/j.ijrmhm.2011.02.004

15. Upadhyaya, G.S. Cemented Tungsten Carbides: Production, Properties and Testing, Noyes Publications, 1998.

16. Spiegler, R., Schmauder, S., Sigl, L.S. Fracture Toughness Evaluation of WC-Co Alloys by Indentation Testing Journal of Hard Materials 1 (3) 1990: pp. 147-158.

17. Antonov, M., Hussainova, I., Pirso, J., Volobueva, 0. Assessment of Mechanically Mixed Layer Developed During High Temperature Erosion of Cermets Wear $263(7)$ 2007: pp. $878-886$. https://doi.org/10.1016/j.wear.2006.12.035

18. Khvan, A.V., Hallstedt, B., Broeckmann, C. A Thermodynamic Evaluation of the $\mathrm{Fe}-\mathrm{Cr}-\mathrm{C}$ System Calphad 46 2014: pp. 24-33. https://doi.org/10.1016/j.calphad.2014.01.002

19. Wiengmoon, A., Pearce, J.T.H., Chairuangsri, T. Relationship Between Microstructure, Hardness and Corrosion Resistance in 20wt.\%Cr, 27wt.\%Cr and 36wt.\%Cr High Chromium Cast Irons Materials Chemistry and Physics 125 (3) 2011: pp. 739-748. https://doi.org/10.1016/j.matchemphys.2010.09.064

20. Schubert, W.D., $\quad$ Fugger, M., Wittmann, B., Useldinger, R. Aspects of Sintering of Cemented Carbides with Fe-based Binders International Journal of Refractory Metals and Hard Materials 49 2015: pp. 110-123. https://doi.org/10.1016/j.ijrmhm.2014.07.028

21. Huang, S., Xiong, J., Guo, Z., Wan, W., Tang, L., Zhong, H., Zhou, W., Wang, B. Oxidation of WC-TiC-TaCCo Hard Materials at Relatively Low Temperature International Journal of Refractory Metals and Hard Materials 48 2015: pp. 134-140. https://doi.org/10.1016/j.ijrmhm.2014.08.002 